under investigation has become wider than was envisaged when the work was begun fourteen years ago. There is increasing evidence of the necessity for pursuing the intensive study of this particular member of a group of diseases affecting, human beings, animals, and plants in close relationship with investigations into virus diseases generally, and of enlisting the experience of workers in other fields of virus research in the elucidation of the problems connected with foot-and-mouth disease. It has been decided in the circumstances that it would be an advantage if the Agricultural Research Council and the Medical Research Council were more actively and directly associated with the work of the committee than at present, and the following have therefore been appointed additional members: Prof. S. P. Bedson, professor of bacteriology in the London Hospital Medical College; Prof. T. Dalling, professor of animal pathology in the University and director of the Animal Diseases Research Institute, Cambridge; Major G. W. Dunkin, director of the Agricultural Research Council Field Station; Mr. G. M. Findlay of the Wellcome Bureau of Scientific Re. search ; Prof. H. B. Maitland, professor of bacteriology in the University of Manchester ; Prof. F. C. Minett, director of the Research Institute in Animal Pathology, Royal Veterinary College, and Mr. J. Henderson Smith, head of the Department of Mycology, Rothamsted Experimental Station.

\section{Fire at the Lister Institute, Elstree}

A FIRE occurred in the chemical laboratories of the Serum Department of the Lister Institute, Elstree, on February 21 ; the cause was the explosion of an acetone-distilling apparatus. The chemical laboratories, dark room, and balance room were completely destroyed, but the adjoining bacteriological laboratories and cold-storage rooms, together with valuable stocks of antitoxins, therapeutic sera, vaccine lymph, and a considerable amount of experimental material were saved through the prompt and efficient work of the staff at Elstree and the local fire brigades. The chemical laboratories were a recent addition to a block of buildings erected by the Institute in 1903 when the Serum Department was under the direction of the late Prof. George Dean. These were afterwards occupied by Mr. Sydney Rowland whilst he was carrying out research for the Indian Plague Commission.

\section{Control of Vehicles in Streets by Traffic Signals}

A PAPER on street traffic signals by F. G. Tyack was read to the Institution of Electrical Engineers on November 4. The descriptions and illustrations given show that modern street traffic signal equipment bears a remarkable similarity to telephone exchange equipment. It is proved that where com. plex switching is required, electrical switching tele. phone apparatus with its ready adaptability forms an ideal solution. Apart from the contribution of the telephone industry, which applies principally to the controllers, other branches of the electrical industry, such as supply lamps, cables and rotating machines, are represented in the necessary equip- ment. The earliest road signals were manually operated and the mechanically controlled 'fixed time' signal came next. This type consists of a mechanism arranged to measure off arbitrarily determined 'go' and 'stop' periods. Fixed time signals was a cheap method of solving the problem of accident prevention. They are found unsuitable when the traffic is variable, as they cause unnecessary delays and bring autonatic signals into disrepute. The logical solution of the problem is that the signals must be operated by the vehicles themselves. The top of a rubber mat projects slightly above the road level. As the channels in the mat are depressed by the wheels of a vehicle, miniature bellows in the contact box become inflated and an electrical contact is made. Impulses indicating the speeds of the vehicles are thus transmitted to the controller. A further step in advance is to have a master controller which, in conjunction with a traffic 'integrator', adjusts the speed of the signal indications to suit the particular traffic density at the time.

\section{Leyden University Botanical Gardens}

THE 350th anniversary of the foundation of the Leyden University Botanical Garden has recently been celebrated. It is the oldest botanical garden in Europe after that of the Vatican (1447), Leipzig (1542), Pisa (1543), Padua (1545), Florence (1546) and Bologna (1567). Only the Gardens of Leyden and Padua have remained in the same place since their foundation. The first catalogue of the Leyden Garden drawn up by Clusen in 1594 contained more than a thousand species of plants, and in the time of Boerhaave this number had risen to 5,800. Numerous Japanese plants were added to the Garden by von Siebold in the nineteenth century.

\section{Medical Research in Canada}

THE conference on the organization of medical research which was held in Ottawa on February 18, and was attended by the Governor-General, has resulted in the formation of a National Medical Research Committee for Canada with five members, who have power to nominate ten others. The chairman is Sir Frederick Banting, professor of medical research in the University of Toronto, and the other members are Major-General A. G. L. Macnaughton, president of the National Research Council; Dr. R. E. Wodehouse, the Deputy Minister of Health and Pensions; Dr. T. H. Leggett, president of the Canadian Medical Association; and Dr. G. S. Young, president of the Royal College of Physicians and Surgeons of Canada.

\section{The Night Sky in March}

The date of the Spring Equinox is March $21^{\mathrm{d}} 7^{\mathrm{h}}$ U.T. The moon is new on March 2 at $5 \cdot 7^{\mathrm{h}}$, and on March 31 at $18 \cdot 9^{\mathrm{h}}$; full moon occurs on March 16 at $5 \cdot 3^{\mathrm{h}}$. Lunar conjunctions with the planets occur as follows : on March $4^{\mathrm{d}} 6^{\mathrm{h}}$ with Saturn; on March $5^{\mathrm{d}} 15^{\mathrm{h}}$ with Mars; on March $28^{\text {d }} 7^{\text {h }}$ with Jupiter. On March $18^{\mathrm{d}} 0^{\mathrm{h}}$ Venus and Saturn are in conjunction; on March $20^{\mathrm{d}} 5^{\mathrm{h}}$ Mercury and Venus, and on March 